\title{
The Determinants of the Profitability of the Tunisian Deposit Banks
}

\author{
Nesrine Ayadi and Younès Boujelbene
}

Université de Sfax, Tunisie

\begin{abstract}
Thanks to the study of twelve Tunisian deposit banks, the researchers were able to identify the influence of these determinants on the bank profitability, using a technique of panel data over the period of 1995-2005. The empirical results suggest that the bank capitalization, as well as the size, have a positive and significant effect on the bank profitability. The empirical results indicate that the variables of financial structure, the ratio of the bank assets to the GDP and that of the stock market capitalization to the banking assets have a negative and a statistically significant effect. As for the impact of the macroeconomic indicators, the researchers conclude that the variables do not have a significant effect on bank profitability. Finally, the results indicate the substitutability between banks and financial markets.
\end{abstract}

Keywords: profitability, bank panel data, Tunisia.

\section{Introduction}

During the last decade, the Tunisian banking sector has undergone major transformations due to the changing environment. The importance of banking in developed economies, its specificity and its role in the financial stability have attracted increasing interest in banks.

Today much of the banking entities are forced to produce new products and seek new customers. Thus, the improvement induced by these changes represents significant challenges for the banks, even the environment in which they operate is changing rapidly; therefore having an impact on their performance. Golin (2001) shows that proportioned revenues are required so that banks can maintain solvency in order to survive, grow and succeed in an appropriate environment.

What about the Tunisian banks? Are they efficient financial institutions which can generate sufficient profitability and dominate the financial landscape? A better understanding of the bank policies requires a deep apprehension of the determinants of bank profitability. Thus, the influence of the fundamental factors on bank profitability is essential not only for the managers of the banks, but also for many stakeholders. In general, the knowledge of these factors would also be particularly interesting to the developing countries whose economies and banking systems are undergoing radical changes nowadays.

Studies dedicated to the analysis of the determinants of profitability, such as those of Molyneux and Thornton (1992) and Staikouras and Wood (2003), have adopted linear internal and external specifications to banks on their performance in terms of profits. Molyneux and Thornton (1992) are the first to examine the determinants of bank profitability in 18 European countries between 1986 and 1989. More recently, the European banking sector was reviewed by Staikouras and Wood (2003) who examined the banks of 13 EU countries over the period 1994-1998.

Copyright (C) 2012 Nesrine Ayadi and Younès Boujelbene. This is an open access article distributed under the Creative Commons Attribution License unported 3.0, which permits unrestricted use, distribution, and reproduction in any medium, provided that original work is properly cited. Contact author: Nesrine Ayadi E-mail: nesrineayadi@laposte.net 
However, with the new global and Tunisian development, several characteristic features have changed since the estimates of Molyneux and Thornton (1992). Thus, in this study, the researchers adopt the same specifications as those of Pasiouras and Kosmidou (2006), to analyze the determinants of performance of the Tunisian banks between 1995 and 2005 .

The researchers, therefore, wonder which variables have the most significant impact to test the effect of the variables of the financial structure on the bank performance.

The remaining part of the paper is organized as follows: In the second section, the researchers synthesize the literature about the determinants of profitability. The empirical methodology is developed in a third section. In Section 4, they test the impact of the internal and external determinants of performance by discussing and summarizing the main results. The last section concludes the article.

\section{Literature Review}

This section examines the main researches on the effects of the specific components of banks, the financial structure and the macroeconomic components of profitability.

\section{The Effects of the Specific Bank Components}

Liquidity risk, which is due to the possible inability of a bank to adapt itself to decrease its liabilities or realize gains on the side of the balance sheet, is considered an important determinant of bank profitability and Net interest margin. The loan market, particularly credit to households and companies is risky and has a higher expected profitability than other assets of the bank, such as the safety of government. Demirguc-Kunt and Huizinga (2001) found a significant negative relationship between liquidity and profitability. Molyneux and Thornton (1992) and Gury et al. (1999) also found a negative relationship between bank profitability and the level of liquid assets held by the bank. Thes e results are in disagreement with those of Bourke (1989) who found a positive and statistically significant relationship. Demirguc-Kunt and Huizinga (2001), Kosmidou (2006) and Kosmidou and Pasiouras (2006) also found a statistically significant positive relationship between liquidity and bank profits.

Therefore, the conclusions about the impact of the banks liquidity on their performance remain unclear and further research is required. Thus, Kosmidou et al., (2005) found a negative and statistically significant relationship between net interest margin and liquidity ratio only when external factors enter the equation. Kosmidou et al., (2004) and Angbazo (1997) also found similar results. These results are in disagreement with those of Clayes and Vender Vennet (2008) who found a positive and statistically significant relationship between net interest margin and liquidity ratio, although it is more pronounced on the Eastern European banking markets. Thus, since the loans are the riskiest capitals and have the highest costs, this foundation refutes the hypothesis that the loan has resulted in wider margins and reflects the ability of the banks to integrate risk considerations and costs in their loan pricing behavior.

\section{H: Liquidity Risk has a Positive Impact on Bank Profitability}

The changes of the credit risk can reflect the changes of the health of a bank loan portfolio which can affect the performance of the enterprise (Cooper et al., 2003). This raises a debate concerning the quality of loan. Duca and Mclaughlin (1990), among others, concluded that the variation of the banking profitability is largely attributable to the variation of the credit risk because the increased exposure to the credit risk is normally connected with the decrease of the firm profitability. This starts a discussion not concerning the volume, but the quality of the loans made. In this direction, Miller and Noulas (1997) suggest that the more the financial institutions are exposed to high risk, the higher the accumulation of the unpaid loans and the 
lower profitability. Athanasoglou et al., (2006) also found a statistically significant negative relationship between the credit risk variable and the bank profitability, proving that banks in South East Europe should focus more on managing credit risk, which was a problem in the recent past.

The serious banking problems have resulted from the failure of banks to identify the impaired assets and create reserves for their cancellation. A great help was given to these assets in that anomalies would be provided by improving the transparency of the financial systems, which will help banks to assess their credit risk more effectively and avoid exposure to dangerous problems. Kosmidou et al., (2005) found a positive but statistically non-significant relationship between the credit risk and bank profitability. Valverde and Fernandez (2007) found that the credit risk increases significantly between bank credit and net profit margin. This reflects that payment by bank loans is more interesting than that by cash, which would increase the net profit margin. Other studies have found similar results (Demirgüç-Kunt and Huizinga, 1999; Demerguç-Kunt and Huizinga, 2001; Maudos and Gerevara, 2004). Therefore, Ho and Saunders (1981) found a generally low but statistically non-significant relationship between the default risk and net interest margin.

\section{$\mathrm{H}_{2}$ : Credit Risk Has A Positive Impact on Bank Profitability}

Capital strength is one of the main determinants of a bank performance. Kosmidou et al., (2005) found a positive and highly significant relationship between the equity ratio to total assets and net profit margin (NIM). Therefore, banks are seeking to lower the cost of their relatively high capital ratios by requiring higher MIN. This basis is in accordance with the interpretation that the capital serves as a signal of bank solvency. Hence, the very high sensitivity of the margins concerning the equity capital ratios to total assets may be explained by the existence of a depositor's behaviour in the banking operations in transition. This can reduce the deposit cost of the well-thriven banks leading to higher profit margins. This result is in accordance with that of other studies, namely Demirguc-Kunt and Huizinga, (1999); Ben Naceur, (2003); Kosmidou and Pasiouras, (2005); Valverde and Fernandez, (2007); Brock and Suarez, (2000); Demirguç-Kunt, Loeven and Levine, (2004) ; and Saunders and Schumacher (2000).

\section{$H_{3}:$ The Strength of The Capital (EQAS) \\ Has A Positive Impact on Bank Profitability}

The bank size is generally used to capture the economies or diseconomies of scale in banking. The relationship between size and profitability is an important part of the firm's theory. The differences in cost, product and risk diversification are consistent with the size of the credit institution. The first factor could lead to a positive relationship between size and bank profitability if the economies of scale are significant (Bourke, 1989; Molyneux and Thornton, 1992; Bikker and $\mathrm{Hu}, 2002$; Goddard et al., 2004). The second factor is negative if the increased diversification leads to a lower credit risk and thus a lower profitability. Kosmidou et al. (2005) found an inverse and statistically significant relationship between size and profitability. The negative coefficient indicates that larger banks tend to earn lower profits, which seems to be consistent with the major studies that found the diseconomies of scale for the larger UK banks which were exposed to a higher overall performance during the period $1988-2002$, using multicriteria approach.

Moreover, the Financial Stability Review, (2002) shows that small banks balance sheets have increased over the last 12 months. In addition, it was suggested that most small banks of British property are more profitable and have a little high ratio of regulation of the public capital. Vender Vennet (1998) found an evidence of economies of scale only for the smallest banks with assets exceeding 10 billion European Currency Unit (ECU) in the EU, with constant returns and then diseconomies of scale for larger banks over 100 billion E.C.U. Similar results were 
obtained in other studies on the European market (Rodrigues et al., 1993; Pallage 1991; Pasiouras and Kosmidou, 2007), Tunisia (Ben Naceur and Goaied, 2005), Australia (Pasiouras et al., 2005) and UK (Kosmidou et al., 2004).

Hassan and Bashir, (2003) also found a significant negative relationship between the bank total assets and profitability. This negative correlation implies that, to some extent, the large size tends to be linked with lower profitability in the Islamic banks. Other researchers, however, conclude that some savings can be achieved by increasing the size of a banking company especially when markets develop (Berger et al., 1987; Althanasoglou et al., 2006). Eichengreen and Gibson, (2001) suggest that the effect of growth on the size of a bank profitability may be positive up to a certain limit.

Beyond this point, the effect of size could have been negative due to some bureaucratic reasons. Therefore, the sizeprofitability relationship may be expected to be nonlinear. Thus, the effect of the bank size on profitability is usually positive and statistically significant, while the relationship is linear (Athanasoglou et al., 2006). By studying the cost characteristics of the various industries in Europe, the Eurpean Committee, (1997) considers this a banking system approach to a high level of sophistication in terms of technology and productivity; an opportunity to exploit the economies of scale. Consequently, the relationship between profitability and bank size weakens over time. Indeed, there is the problem of the bank optimal size for the purpose of maximizing the margin. It appears that the net interest margin of banks seems to depend on their size. Thus, according to Kosmidou et al. (2005), there is an inverse and statistically significant relationship between the size and the net profit margin. The negative coefficient indicates that larger banks tend to earn margins, the thing that seems consistent with the studies that found economies of scale for smaller banks and diseconomies of scale for larger ones. Similarly, Ben Naceur and Goaied, (2005) and Clay and Vender Vennet, (2008) found a statistically significant negative relationship between the size and the net profit margin. The results of Demirguç-Kunt and Huizinga, (1999) and Demirguç-Kunt, Loeven and Levine, (2004) disagree with those of the previous studies since they found a negative relationship between the size of the bank and its profit margin. Therefore, large banks seem to have lower interest margins than the smaller ones. This seems to be consistent with the models that show the positive role of the size resulting from scale efficiency.

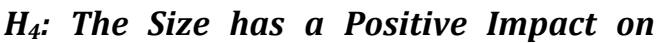 Bank Profitability}

\section{The Effects of the Financial Structure}

\section{Literature Focuses on Two Sets of Financial Structures:}

Literature of the first set of the financial structure focuses on competition and performance in the banking sector. It includes the structural and non-structural approaches (see Berger et al., 2004). The structural approaches embrace the assumption of the structure-conductperformance (SCP) and the efficient structure hypothesis. This was confirmed by Kosmidou et al., (2005). These assumptions try to show, respectively, whether a highly concentrated market causes collusive behavior among the largest banks resulting in a superior performance of the market and also if effectiveness of the largest banks increases their performance. However, the non-structural approaches, which resulted from literature in the new empirical industrial organization (NEIO), examine the competition by using the market strength because they have a constraint in analyzing the competitive behavior of the banks in the absence of structural measures.

The SCP hypothesis, which was partially supported theoretically in the context of literature NEIO by Bikker and Bos (2005), says that banks can extract monopolistic rents in concentrated markets thanks to their ability to provide lower guarantee deposits and change the higher borrowing rates because of the collusion or other forms of non-competitive behavior. The 
more the market is concentrated, the lower the degree of competition is. The smaller the number of companies is, the more the market structure is concentrated, and the more likely that companies in a market will produce a common output price. This configuration comes closer to the monopoly solution.

Thus, companies in a more concentrated market earn higher profits than those operating in a less concentrated one regardless of their effectiveness. However, the hypothesis of the structure shows that an effective concentration may reflect the firm-specific efficiencies (see Berger, 1995a). If concentration becomes insignificant, it goes against the hypothesis of the structure-conduct-performance. Molyneux and Thornton, (1992) found a positive and statistically significant relationship between concentration and profitability, which is consistent with the traditional paradigm of the structureconduct-performance. The results of Kosmidou et al., (2005) suggest that the positive impact of concentration, which is measured by the ratio, reflects the structure of an oligopolistic market- the fact which supports the hypothesis of SCP and the empirical results of Demirguç-Kunt and Huizinga, (1999); Hassan and Bashir, (2003); and Athanasoglou et al., (2006). Thus, banks are becoming more profitable either when they develop other activities or when they are larger.

The results of these studies concur with those of Ben Naceur and Goaied, (2005) who found that concentration is less beneficial than competition for the Tunisian commercial banks in terms of profitability. This implies that the monopoly of big banks is an obstacle to profitability. However, the basic recommendation would then be to focus on the development of competition in the banking system. Similarly, DemirgüçKunt, Loeven and Levine, (2003) found a positive and statistically significant relationship between concentration and net profit margin. Ben Naceur and Goaied, (2005) found that concentration has a negative and significant impact on the net profit margin. This means that concentration is less beneficial than competition to the Tunisian commercial banks in terms of performance. However, the results of Clayes and Vender Vennet, (2008) are mitigated. First, the assessment backs the hypothesis of the SCP in the whole sample. Thus, the concentration ratio coefficient is positive and highly significant in all the regressions for the variables of some specific banks along with the effects of time and countries. Thus, an increase in market concentration has a positive effect on the bank margins which is an indicator of collusion.

As far as the Western sample is concerned, Clayes and Vender Vennet (2008) also found an evidence of collusion in all the estimated specifications. However, the coefficients for the macroeconomic control variables are negative. The banking markets of Western Europe are usually competitive because of the extensive efforts of the financial deregulation, the harmonization of standardization and the convergence of macroeconomic and monetary environment. Bandt and Davis, (2000) found that the European banks were characterized by a monopolistic competition before the EMU. However, Corvoisier and Grapp, (2002) show that increased concentration is due to a consolidation in the European banking. They found that loans and deposits may have resulted in price fixing by less competitive banks. But, Gandat-Larralde and Lepetit, (2001) found a positive relationship between market concentration and bank performance in a sample of eight Western European countries during the period 1992-1996 under the assumption of SCP.

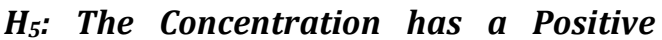 Impact on Bank Profitability}

The second set consists of variables of financial structure which measure the importance of both the relative GDP of bank and stock market or the importance to each other. This is the reason for which these variables can also be built on arguments of the market strength. These variables may reflect a complementary or substitutable attitude between the bank and the stock market. The Modigliani-Miller theorem 
states that debt financing and financing through capital increase may also be complementary as the model of Boyd and Smith (1996) states.

Demirguc-Kunt and Maksimovic (1996) provide empirical evidence that an ability to attract equity capitals may also increase the borrowing capacity of the firms, particularly in the stock markets of the developing countries. Funding through raising the capital can increase and decrease the demand for financing through debt, there by reflecting that these sources are complementary.

Thus, concerning the importance of the bank relative GDP, Demirguç-Kunt and Huizinga, (1999) found that in countries where the banking assets represent a large part of the GDP, the banks are less profitable. They also found that the ratio of bank assets to the GDP, which has a significantly negative impact on the margin, may reflect a more intense inter-bank competition in the financial systems. This effect is negligible in richer countries that already have a relatively developed banking sector. However, in countries with underdeveloped financial systems, a greater financial development, which improves the efficiency of the banking sector, potentially leads to growth at the micro, firm and the macro level. Thus, the improved availability of funds financing for companies can increase their borrowing capacity (Demirguç-Kunt and Huizinga, 2001). Pasiouras and Kosmidou, (2007) found that the total bank assets to the GDP are negatively related to profitability.

\section{H$_{6}:$ Total Bank Assets to GDP (ASSGDP) have a Positive Impact on Bank Profitability}

Regarding the importance of the GDP related to the stock market, Demirguc-Kunt and Huizinga, (1999) indicate that the ratio of the stock market capitalization to the GDP is positively related to the equation of the net profit margin. This suggests that greater equity markets inherently allow banks to obtain higher profit margins, the thing which supports the hypothesis of complementarity between financing through raising funds and through debt. Therefore, while the stock market develops, a better availability of information increases the common potential funds of the borrowers, a way to enable the banks to identify and monitor them thereby increasing the volume of the business, making then the margins very high. Demirguc-Kunt and Huizinga (2001) also found that even in the underdeveloped financial systems, the development of the stock market improves the bank margins. In addition, the available information, which the stock market requires, allows the banks to better evaluate their credit risk. Thus, the positive and statistically significant relationship between the stock market capitalization to total assets of the banks and the stock market capitalization to the GDP indicates that a greater stock market, compared to the economy or to the banking sector, increases the bank profits. These results confirm the empirical results of Ben Naceur and Goaied (2005) who examined the Tunisian banking sector and suggested that while the stock market expands, more information becomes available. This leads to an increase in the number of bank potential customers which makes the process of identifying and monitoring the borrowers easier. Therefore, this increase in the bank activity will contribute to the increase in profitability.

\section{H7: Total Bank Assets to GDP (ASSGDP) Have a Positive Impact on Bank Profitability}

Subsequently, the relationship between the ratio of market capitalization to bank assets and the net profit margin is negative. Thus, maybe a larger stock market relating to the banking sector reduces bank margins, thus reflecting the possibility of substitution between debt and equity capitals (Demirguc-Kunt and Huizinga, 2001). Similarly, Kosmidou et al., (2005) also found similar results between stock market capitalization and performance. They indicate that a larger stock market relating to the banking sector increases margins. This leads to an increase in the future number of bank customers by creating an easier process for identifying and 
monitoring the borrowers. Therefore, this increase in the banks activities contributes to a better performance. These results are in consistence with those of Kosmidou et al., (2005) who found that a larger market share relating to the banking sector increases profitability. However, the empirical evidence of Demirguç-Kunt and Huizinga, (2001) suggests that banks in the underdeveloped financial systems have higher profits. Thus, for some level of financial development, the financial structure, that is to say the relative development of banks against the markets, does not have an independent effect on the bank performance. However, they found that in the developed financial systems, the profits are not in fact statistically different across the systems based on banks and those based on markets. The results indicate that more development banks lower their profits. This banking development can then cause a stiffer competition, a higher output and a lower profit. Demirguç-Kunt and Huizinga (2001) also show that in the underdeveloped financial systems, the growth of the stock market improves the profits. This reflects the complementarity between the bank and the growth of the stock market. Specifically, the growth of the stock market and the improved availability for banks to finance through equity capitals can increase their borrowing capacity. This can lead to higher bank profits. Indeed, for countries with an underdeveloped financial system, a greater financial development would improve the banking sector efficiency.

\section{$H_{8}$ : Market Capitalization to Bank Assets (Macpass) Has a Negative Impact on Profitability}

\section{The Effects of Macroeconomic Components}

Bank profitability and bank net profit margin are sensitive to the macroeconomic conditions despite the industry tendency towards a greater geographic diversification and greater use of financial engineering techniques to manage the risk associated with the forecasts of the economic cycle. Thus, the macro-economic indicators are the GDP growth and inflation. Demirguç-Kunt and Huizinga, (1999) define growth as the one of the GDP per real capital. This variable is insignificant. Ben Naceur and Goaid, (2005) also found that growth does not reflect any aspect of the banking regulation and the advanced technology in the banking sector. So, these results are in a disagreement with those of Kosmidou et al., (2005) who found a positive and a statistically significant relationship between the GDP growth and performance. This theory is consistent with those of Pasiouras and Kosmidou, (2007); Kosmidou, (2006); Kosmidou and Pasiouras, (2005); and Hassan and Bashir (2003), which support the argument of the positive association between the GDP growth and the financial performance of the sector. However, the results of Demirguç-Kunt, Loeven and Levine (2003) disagree with those of Kosmidou et al., (2005), and state that economic growth is weakly associated with a decrease in the margin, while the results of Clayes and Vender Vennet (2008) are mitigated.

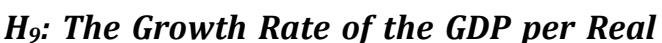 Capital (GDPGGR) Has a Positive Impact on Bank Profitability}

Revell (1979) introduced the notion that the effect of inflation depends on wages and other operating costs of banks which are increasing at a faster rate than inflation. As such, the relationship between inflation and profitability is ambiguous and depends on whether inflation is expected or not. The inflation rate fully anticipated by the management of the bank implies that banks can appropriately adjust the interest rates to increase their products faster than their costs and then gain higher profits. In contrast, unanticipated inflation could lead to an incorrect adjustment of the interest rates and therefore to the possibility that costs may rise faster than products. Thus, Ben Naceur and Goaid (2005) found that banks tend not to gain profits in an inflationary environment. Therefore, most studies (i.e. Bourke, 1989; Molyneux and Thornton. 1992) observe a positive relationship between inflation and banking performance. 
Demirguç-Kunt and Huizinga, (1999) showed that with the inflation, banks costs tend to rise. However, a greater number of transactions may lead to higher labor costs as shown by Hanson and Rocha (1986); a result of a high ratio of the branch banking capital.

\section{H10: the Inflation Rate (INF) has a Positive Impact on Bank Profitability}

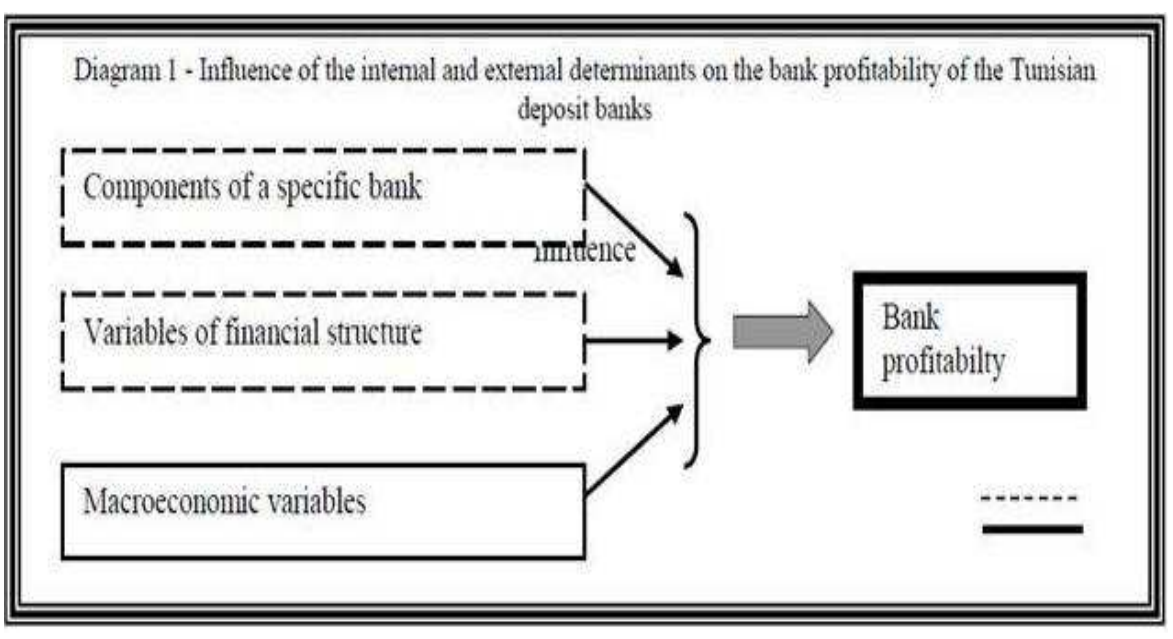

Source: carried out by the author

The researchers will now try to measure this influence.

\section{Methodology}

The methodology of this study is described through two main dimensions: the studied sample (3.1) and the statistical processing method carried out (3.2).

\section{The Sample Selection}

The single data used in the empirical work were extracted from the database of the Tunisian Central Bank. The sample includes twelve deposit banks. The researchers had a regular series of data from 1995 to 2005. The financial structure and the macroeconomic data are respectively derived from the Tunisian stock market (Tunis Stock Exchange) and the Tunisian National Institute of Statistics (TNIS).

\section{Treatment of Statistical and Applied Variables}

\section{Econometric Specification}

To examine the internal and external factors affecting the profitability of the Tunisia banks, the following model was developed:

$$
Z_{i t}=\alpha_{i t}+\alpha_{m i t} Y_{m i t}+\alpha_{d i t} Y_{d i t}+\varepsilon_{i t}
$$

Where:

- i refers to an individual bank,

- $t$ refers to the year,

- $\mathrm{z}$ is the dependent variable referring to the profitability on the average assets (ROAA),

- Ym is a vector of the internal factors of a bank,

- Yd is a vector of the external factors of a bank.

The final detailed model is then as follows:

$R O A A_{t t}=\alpha_{0}+\alpha_{1} B L O A N+\alpha_{2} L I Q_{t}+\alpha_{3} E Q A S_{t t}+\alpha_{4} S I Z E_{t t}+\alpha_{5} C O N C_{t t}$ $+\alpha_{6} A S S G D P+\alpha_{7} M A C P A S S_{t}+\alpha_{8} M A C G D_{i t}+\alpha_{9} G D P G G R+\alpha_{10} I N F_{i t}+\varepsilon_{i t}$

Estimating the panel model helps apply a model of fixed effects or model of random effects (Hausman, 1978). The first step is to find out if there are some individual effects in our data. These effects can be represented by an intercept specific to each 
individual, ui. The researchers then seek to test the null hypothesis Ho: ui $=0$ in the regression. The null hypothesis of this test shows that there is only one common intercept and no individual effect. The result is an F statistic with (N-1, NT-NK-1) degree of freedom. If the null hypothesis is rejected, then individual effects must be included in the model. Thus, it is found that we are dealing with an individual effect in our case, because $F(11.110)=5.32>0$.

The second step is to make a specification test of the effects to see if they are fixed or random. The models of fixed effects and random effects can take into account the data heterogeneity, but the assumptions about the nature of the specific effects differ from one model to another. In the first case, it is assumed that the specific effects may be correlated with the explanatory variables of the model, and in the second case it is assumed that the specific effects are orthogonal to the explanatory variables of the model. The Hausman specification test can show which of these assumptions is appropriate to the data. In other words, this test helps to choose between the model of fixed effects and that of random effects. In a model of fixed effects (FE), the parameters to be estimated are considered fixed, while in a model of random effects (RE), the parameters to be estimated are random and the estimation method is generalized least square (GLS ). Thus, there is strong evidence that the researchers' specification follows a random model (RE) as an indication of the Hausman test ( $\mathrm{p}$ value equals $0.4611>10 \%$ ). That is why the researchers' model is estimated by the generalized least square method (GLS), taking the bank ROAA as a dependent variable (Table 1).

\section{Table 1- Test for the Presence of an Individual Effect, and Test of Effect Specification (Hausman Test)}

\begin{tabular}{|c|c|}
\hline \multicolumn{2}{|c|}{$\begin{array}{l}\text { The notation used in the table below is defined as follows: BLOAN is a measure of the credit risk calculated as } \\
\text { the ratio of the bank credit to the total assets; LIQ is a measure of liquidity risk calculated as the ratio of the } \\
\text { liquid assets to the customer and short-term investment; EQAS is a measure of capitalization calculated as the } \\
\text { book value of equity capitals as a fraction of the total assets; SIZE is a measure of the size that is equal to total } \\
\text { assets; CONC is a measure of the concentration calculated as the ratio of the total assets of the largest banks } \\
\text { to the total assets of all the banks; MACGDP measures the importance of the GDP relating to the stock } \\
\text { market; ASSGDP measures the importance of the GDP relative to banks; MACPASS measures the market } \\
\text { capitalization to the bank assets; GDPGGR is the economic growth; INF is the inflation rate. }\end{array}$} \\
\hline & ROAA \\
\hline Constant & $0.0226879(1.40)$ \\
\hline \multicolumn{2}{|c|}{ Variables specific to banks } \\
\hline BLOAN & $-0.0005532(-0.68)$ \\
\hline LIQ & $-0.0006067(-0.76)$ \\
\hline EQAS & $.0473187(3.23)^{* * *}$ \\
\hline SIZE & $-1.37 \mathrm{e}-11(-0.01)$ \\
\hline \multicolumn{2}{|c|}{ Variables of financial structure } \\
\hline CONC & $0.0417714(1.00)$ \\
\hline ASSGDP & $-0.0348881(-3.61)^{* * *}$ \\
\hline MACPASS & $-0.2232438(-3.06)^{* * *}$ \\
\hline MACGDP & $0.2247523(3.43)^{* * *}$ \\
\hline \multicolumn{2}{|c|}{ Macroeconomic variables } \\
\hline GDPGGR & $-0.0003529(-1.57)$ \\
\hline INF & $-0.0010383(-1.74)$ \\
\hline$R^{2}$ & 0.3472 \\
\hline$F(11,110)$ & $5.32^{* * *}$ \\
\hline No of observations & 132 \\
\hline $\operatorname{chi} 2(9)$ & 8.75 \\
\hline Hausman Test & 0.4611 \\
\hline
\end{tabular}




\section{The Used Variables}

As previously mentioned, the empirical part of this article tries to examine the determinants of the performance of the Tunisian commercial property banks. Four banking characteristics are used as internal determinants of performance. In addition, four indicators of financial structure and two macroeconomic indicators are used as external determinants. The variable chosen to measure the performance of banks is the profitability of the average assets.

\section{Measuring the Dependent Variable: Performance Measurement}

Consistent with the recent studies that have examined the determinants of bank profitability, the financial ratios are also used as a measure of performance in this study. To measure bank performance, the researchers use the profitability over the average assets (ROAA) calculated as the net profit after tax divided by the average of the total assets. This is probably the highest ratio chosen by comparing efficiency to performance. This study indicates that profitability is generated from the assets the bank owns.

\section{Measuring the Independent Variables}

Four bank characteristics are used as internal determinants of performance. These are: the ratio of equity to total assets; the ratio of bank credit to total assets; the ratio of liquid assets divided by customers and short term investment; and the total assets of the bank.

The ratio of equity capital to total assets (EQAS), which is considered one of the basic ratios for the capital strength, is used in this study as a measure of the capital strength (Golin, 2001). Therefore, strength capital is related to the safety and strength of banks. In general, banks with a high capital ratio are considered more secure in case of loss or liquidation. Therefore, the assumption of risk agreement profitability would imply a negative relationship between the ratio of equity capitals and bank performance. The ratio of equity capitals to total assets is expected to be higher, requiring a low external investment, and therefore bank profitability would be higher. The risk decline increases the solvency of banks; hence reducing the investment cost.

Golin (2001) states: "It is critical to carefully supervise the banks against liquidity risk - Liquidity risk is the fact that it won't have enough current assets such as money and securities rapidly salable to meet the current commitments for example, those of the depositors particularly during the periods of economic stress." Without required liquidity and investment to meet its commitments, a bank may go bankrupt. The ratio of liquid assets to the customer and to short term investment (LIQ) is used in this study as a measure of liquidity. It is a ratio that indicates which percentage of customers and short term investments could be met if they were suddenly withdrawn. Therefore, the higher the percentage is, the more liquid and the less vulnerable the bank is during a traditional bank route. A negative relationship between this variable and EBITDA is expected.

Bank loans are considered a main source of income. The researchers expect the bank loan ratio to the assets (BLOAN) to have a positive impact on profitability. Otherwise, the more the deposits are processed in loans, the higher the profits are. However, if a bank has to increase the risk to have a higher credit ratio to the assets, profits may consequently decrease.

The last feature of the bank dealt with in this study is the bank size, which is measured by its total assets. The size of the bank (SIZE) is regarded as an important determinant of profitability. A large bank may result in economies of scale that reduce the cost of collecting and processing information (Boyd and Runkle, 1993). As in most studies on banking, the researchers use the total assets of the bank as a proxy variable so that its size represents the size related to the economies or the diseconomies of scale. 
In addition, six external determinants were used to examine the environmental impact on profitability. Two sets of variables were considered in this study showing the financial structure and the macroeconomic conditions.

In this study, there is an endeavor to examine how bank performance is linked to the relative development of the banking sector and stock market using ratios of the stock market capitalization to the GDP (MACGDP) and to the total assets of the deposit banks (MACPaSS), and the total assets of deposit banks to the GDP (ASSGDP) and the banking sector concentration (CONC).

The concentration of commercial banks (CONC), which is calculated as the total assets held by the four largest commercial Tunisian banks divided by the total assets of all the commercial banks in the country, is considered an external indicator in this study. Under the assumption of StructureConduct-Performance (SCP), when the banks are highly concentrated, the markets tend to agree and thus earn monopoly profits (Short, 1979; Gilbert 1984). It is expected that the concentration is positively related to bank profitability.

ASSGDP and MACGDP respectively measure the overall level of development of the banking sector and the stock market, as well as their importance in financing the economy. Both variables are expected to affect profitability positively.

MacPass reflects the complementary or substitutable attitude between the bank and the financial market. Demirguc-Kunt and Huizinga, (1999) found that market capitalization to the banking assets is negatively related to the margins suggesting that a relatively well developed stock market may substitute the bank financing. The researchers, therefore, expect that this variable is negatively related to the bank performance. Both of the macroeconomic variables used here are the growth of the gross domestic product (GDP) and inflation (INF). The GDP growth (GDPGR) is among the macroeconomic indicators most commonly used. It is a measure of all the economic activity expected to have an impact on many factors related to the supply and demand for loans and deposits. The real GDP growth used in this study is expected to have a positive relationship with profitability. Inflation (INF) can affect the costs and revenues of any organization, including banks. Perry, (1992) states that the effect of inflation on bank profitability depends on whether inflation is expected or not. 
Table 2- Definition, Notation and Expected Effect of the Explanatory Variables of Banking Profitability

\begin{tabular}{|c|c|c|}
\hline \multicolumn{3}{|c|}{ Dependent variables } \\
\hline ROAA & \multicolumn{2}{|c|}{$\begin{array}{l}\text { "Return on assets » is the ratio of the net profit net after tax to total average } \\
\text { assets (F Pasiouras and K Kosmidou, 2006). }\end{array}$} \\
\hline \multicolumn{3}{|c|}{$\begin{array}{l}\text { Independent variables } \\
\end{array}$} \\
\hline \multicolumn{3}{|c|}{ Specific bank components } \\
\hline & & Expected sign \\
\hline BLOAN & $\begin{array}{l}\text { The credit risk ratio is defined as "bank credit /total asset" } \\
\text { (Maudas and Guevara, 2004). }\end{array}$ & $(+)$ \\
\hline LIQ & $\begin{array}{l}\text { The liquidity risk ratio is used as a proxy "liquid asset / } \\
\text { customer and short-term investment" (Valverde and } \\
\text { Fernandez, 2007). }\end{array}$ & $(-)$ \\
\hline EQAS & $\begin{array}{l}\text { The financial strength of the bank is equal to the } \\
\text { shareholders' equity divided by the total assets (F Pasiouras } \\
\text { and } \\
\text { K Kosmidou, 2006). }\end{array}$ & $(+)$ \\
\hline SIZE & Value of total assets (F Pasiouras and K Kosmidou 2006). & (?) \\
\hline \multicolumn{3}{|c|}{ Financial structure components } \\
\hline CONC & $\begin{array}{l}\text { The measure of concentration is equal to the total assets of } \\
\text { the largest banks divided by total assets of all banks. } \\
\text { (F Pasiouras and K Kosmidou, 2006). }\end{array}$ & $(+)$ \\
\hline ASSGDP & $\begin{array}{l}\text { Is equal to the deposit bank total assets divided by the GDP } \\
\text { (F Pasiouras and K Kosmidou, 2006). }\end{array}$ & $(+)$ \\
\hline MACPASS & $\begin{array}{l}\text { Is equal to the market capitalization divided by the deposit } \\
\text { bank total assets (F Pasiouras and K Kosmidou, 2006). }\end{array}$ & $(-)$ \\
\hline MACGDP & $\begin{array}{l}\text { Is equal to the market capitalization divided by the GDP (F } \\
\text { Pasiouras and K Kosmidou, 2006). }\end{array}$ & $(+)$ \\
\hline \multicolumn{3}{|c|}{ Composantes macroéconomiques } \\
\hline GDPGGR & $\begin{array}{l}\text { The real growth of the Gross Domestic Product (F Pasiouras } \\
\text { and K Kosmidou, 2006). }\end{array}$ & $(+)$ \\
\hline INF & $\begin{array}{l}\text { The annual inflation rate is the variation of the family } \\
\text { consumer price index (F Pasiouras and } \mathbf{K} \text { Kosmidou, } \\
\text { 2006). }\end{array}$ & (?) \\
\hline
\end{tabular}

\section{Empirical Results and Interpretations}

In what follows, the descriptive statistics are presented, followed by the constructed regression model on the internal and external factors on the performance of Tunisian banks with the empirical results and their interpretations. 


\section{Descriptive Statistics}

Table 3 - Descriptive Statistics of the Variables Used to Analyze the Sample of the Tunisian Banks between 1995 and 2005

\begin{tabular}{||l|l|l|l|l|l||}
\hline Variable & Obs & Mean & Std. Dev. & Min & Max \\
\hline EQAS & 132 & 0.0877715 & 0.0302836 & 0.0214245 & 0.1685182 \\
\hline SIZE & 132 & 1601970 & 1076748 & 87844 & 4399155 \\
\hline BLOAN & 132 & 0.7729057 & 0.4253569 & 0.0085761 & 5.101068 \\
\hline LIQ & 132 & 0.2775946 & 0.4991695 & 0 & 3.230628 \\
\hline CONC & 132 & 0.5775732 & 0.0138725 & 0.5464084 & 0.5972372 \\
\hline ASSGDP & 132 & 1.295444 & 0.2147558 & 0.9606633 & 1.589214 \\
\hline MACPASS & 132 & 0.1614946 & 0.0681837 & 0.0990744 & 0.3158439 \\
\hline MACGDP & 132 & 0.1970335 & 0.0496608 & 0.1503616 & 0.3034197 \\
\hline INF & 132 & 3.209091 & 1.14248 & 1.9 & 6.3 \\
\hline GDPGGR & 132 & 4.790909 & 1.526831 & 1.7 & 7.1 \\
\hline ROAA & 132 & 0.008362 & 0.0060102 & -0.0032635 & 0.0282273 \\
\hline
\end{tabular}

According to the descriptive statistics reported in table 3 , the 12 Tunisian deposit banks recorded between 1995 and 2005 an average of $0.836 \%$ for ROAA. Other researchers note that the Tunisian commercial banks have rarely exceeded 1\% in ROAA during the period 1990-1997. In addition, the average size of the banks in the sample during the study period was $1,601,970$ thousand Tunisian Dinars. So, they are deemed to be small compared to the European or other commercial banks. Moreover, the capital strength of these banks, on average, is equal to $8.777 \%$ during the period of our study, the thing which verifies that well-capitalized banks face lower bankruptcy costs. It appears that credit risk is very high at an average of
$77.290 \%$ during the period 1995 to 2005, which means that the Tunisian economy applies an economy of debt. The average liquidity risk is $27.759 \%$. In addition, the average concentration among banks is $57.757 \%$. These results are consistent with those in the study of Levine et al., (2004) which focuses on the emerging markets, where banks are characterized by the concentration of ownership because of government involvement and foreign investors in their capital.

\section{The Results of the Regression}

Table 4 and 5 respectively Relate the Correlation Matrix and the Regression Results of our study to profitability.

Table 4 - Correlation Matrix

\begin{tabular}{|c|c|c|c|c|c|c|c|c|c|c|}
\hline & EQAS & SIZE & BLOAN & LIQ & CONC & ASSGDP & MACPASS & MACGDP & INF & GDPGGR \\
\hline EQAS & 1.0000 & & & & & & & & & \\
\hline SIZE & 0.1019 & 1.0000 & & & & & & & & \\
\hline BLOAN & 0.1123 & 0.1595 & 1.0000 & & & & & & & \\
\hline LIQ & -0.3829 & -0.2321 & -0.1867 & 1.0000 & & & & & & \\
\hline CONC & -0.0355 & 0.0361 & 0.0695 & 0.0197 & 1.0000 & & & & & \\
\hline ASSGDP & 0.2889 & 0.3000 & 0.1287 & -0.4931 & 0.0588 & 1.0000 & & & & \\
\hline MACPASS & -0.2195 & -0.2594 & -0.0494 & 0.3398 & 0.2857 & -0.8377 & 1.0000 & & & \\
\hline MACGDP & -0.1558 & -0.2175 & -0.0034 & 0.2161 & 0.3170 & -0.6695 & 0.9577 & 1.0000 & & \\
\hline INF & -0.1958 & -0.2070 & -0.1252 & 0.3221 & 0.4388 & -0.7040 & 0.7883 & 0.6745 & 1.0000 & \\
\hline GDPGGR & 0.0098 & -0.0431 & 0.1018 & 0.0268 & -0.2646 & -0.1357 & -0.0092 & -0.0297 & -0.2179 & 1.0000 \\
\hline
\end{tabular}


Examination of the correlation coefficients, allows us to study the null hypothesis of no correlation between explanatory variables. We must therefore set the limit value of the correlation coefficient to specify our models. We set this limit to 0.8 (Kennedy, 1985): that is to say whether the correlation between two variables is exceeds 0.8, these two variables should not be in the same model to ensure the effectiveness of the interpretation of results. As shown in the table above, all correlation coefficients are smaller than 0.8 at which the phenomenon of colinearity is becoming more pronounced. It follows that the correlation between the explanatory variables in our models may be acceptable. So there is no problem of multicollinearity.

Table 5 - Results of Estimating the Random Effects RE (Dependent Variable: ROAA)

\section{Cross-sectional time-series FGLS regression \\ Coefficients: generalized least squares \\ Panels: homoskedastic \\ Correlation: no autocorrelation}

The notation used in the table below is defined as follows: BLOAN is a measure of the credit risk calculated as the ratio of the bank credit to the total assets; LIQ is a measure of liquidity risk calculated as the ratio of liquid assets to the customer and short-term investment; EQAS is a measure of capitalization calculated as the book value of equity as a fraction of total assets; SIZE is a measure of the size that is equal to total assets; CONC is a measure of concentration calculated as the ratio of total assets of the largest banks to the total assets of all the banks; MACGDP measures the importance of GDP relative to the stock market; ASSGDP measures the importance of the GDP relative to the bank; MACPASS measures the market capitalization to the bank assets; GDPGGR is the economic growth; INF is the inflation rate.

\begin{tabular}{|l||c|}
\hline & ROAA \\
\hline Constant & $0.024591(1.36)$ \\
\hline
\end{tabular}

\section{Variables specific to banks}

\begin{tabular}{|l||c|}
\hline BLOAN & $0.0007164(0.87)$ \\
\hline LIQ & $-0.0010039(-1.20)$ \\
\hline EQAS & $0.068772(5.68)^{* * *}$ \\
\hline SIZE & $3.34 \mathrm{e}-09(10.11)^{* * *}$ \\
\hline
\end{tabular}

Variables of financial structure

\begin{tabular}{|l||c|}
\hline CONC & $0.0472824(1.01)$ \\
\hline ASSGDP & $-0.0451896(-4.36)^{* * *}$ \\
\hline MACPASS & $-0.2523725(-3.08)^{* * *}$ \\
\hline MACGDP & $0.2499781(3.39)^{* * *}$
\end{tabular}

Macroeconomic variables

\begin{tabular}{|l||c|}
\hline GDPGGR & $-0.0004433(-1.76)$ \\
\hline INF & $-0.0009455(-1.40)$ \\
\hline$R^{2}$ & 0.3472 \\
\hline$F(11,110)$ & $5.32^{* * *}$ \\
\hline No. of observations & 132 \\
\hline
\end{tabular}

\section{The Bank Features}

The first bank characteristic is the book value of equity capitals divided by the total assets (EQAS). The basic specifications confirm a positive relationship between capitalization and ROAA. These results are consistent with those of Buser, Chen and Kane, (1981) who also examined the theoretical relationship between profitability and bank capitalization. They found that banks have generally within 
them an optimal funding ratio. Banks with a high exempt value reflecting a rich bank input have incentives to remain wellprofited and to engage in a prudent lending behavior (Stuglitz and Uy, 1996). Berger, (1995b) provides empirical evidence that the U.S. banks show a positive relationship between bank profitability and capitalization, although the evidence is not conclusive. He notes that well-capitalized companies are facing very low expected bankruptcy costs for themselves, and therefore their customers reduce their cost of investment (Table 5).

Then, there is a positive and statistically significant relationship between size (SIZE) and ROAA indicating the existence of economies of scale in the Tunisian banking sector. By studying the cost characteristics of various industries in Europe, the European Commission (1997) reports this as a banking system approach at a high level of sophistication in terms of technology and productivity, which represents an opportunity for exploiting the economies of scale that could be quite limited (Table 5).

Similarly, the relationship between credit risk (BLOAN) and performance is positive but not statistically significant. This reflects that payment by bank loans is more interesting than that by cash since it increases profitability. Thus, this result confirms those found by Kosmidou et al., (2005) and Valverde and Fernandez, (2007).

It can also be seen that the relationship between liquidity risk (LIQ) and performance is negative. Thus, a weak inverse relationship with profitability can be sustained by the fact that, generally, the liquidity held by banks, including those authorized by the state, has an important cost to the banks. These results, though identical to those of Molyneux and Thornton, (1992), disagree with the results of Bourke, (1989) who found a positive and statistically significant relationship (Table $5)$.

\section{Variables of Financial Structure}

In the regression reported in table 5, two sets of financial structure variables are included.

The first set includes the ratio of the market concentration as an indicator of market structure. Various authors, such as Gilbert, (1984) and Berger (1995a), indicate that this variable can get the market strength as well as the differences in the bank efficiency.

The second set consists of the financial structure variables that measure the importance of the GDP relative to the bank and to the stock market and between them, the reasons for which the particular case in hand of these variables can also be built on arguments of the market strength. A high ratio of bank credit to the GDP, for example, may reflect a high demand for banking services that create competition between banks. Thus, these variables may reflect the complementary or substitutable attitude between the bank and the stock market. The Modigliani-Miller theorem states that debt financing and financing through raising capital may also be complementary, like the model of Boyd and Smith, (1996). Demirguc-Kunt and Maksimovic, (1996) provide empirical evidence that an ability to attract equity capital may also increase the firm borrowing capacity, particularly in the financial markets of the developing countries. In this set, funding by raising the capital may increase rather than reduce the demand for debt financing, reflecting that these sources are complementary.

Turning to the first set of financial structure variables, it is obvious that the bank concentration ratio (CONC) has a non significant and positive impact on bank profitability, and hence is in accordance with the literature that wants them to be positively related. Subsequently, since concentration remains insignificant, this does not confirm the hypothesis of a traditional paradigm of Structure-ConductPerformance (SCP). 
The second set of the financial structure variables affects bank profitability. This may show that these variables have a greater impact on bank lending and on consumer deposit than on other customers.

Thus, the ratio of the bank assets to the GDP (ASSGDP) has a negative and statistically significant impact on bank profitability, reflecting a more intense inter-bank competition in the financial systems. This effect weakens in the richer countries that already have a developed banking sector. The results of this study are consistent with those of Demirguc-Kunt and Huizinga, (1999) who found that banks are less profitable in countries where the banking assets constitute a large part of the GDP.

The ratio of the stock market capitalization to the bank assets (MACPASS) is negatively related to the asset profitability. This suggests that a stock market relating to the banking sector lowers bank profitability, reflecting a possible substitutability between debt and equity capitals. Results of the means of the financial structure indicate that the movement of the Tunisian financial system towards a market-based one is more profitable than a system based on banks. These results confirm those of Demirguc-Kunt and Huizinga, (2001) which showed that in underdeveloped financial systems, the stock market development improves the profits. However, the results of Demirguc-Kunt and Huizinga, (2001) reflect the complementary attitude between the bank and the stock market development. These results are in disagreement with those of the present study which shows that a substitutable attitude between the bank and the stock market. Thus, Demirguc-Kunt and Huizinga, (2001) found that the development of the stock market and the improved availability of equity capital financing for companies can increase their borrowing capacity. This leads to an increase in the number of potential customers making it easy for banks to identify and control the borrower and increase bank profits. However, at higher levels, a developed stock market reflects the differences in the bank financing cost for the companies. Indeed, for countries with underdeveloped financial system, a greater financial development improves the efficiency of the banking sector.

The ratio of the stock market capitalization by the GDP (MACGDP) is positively related to the profitability of the asset. This suggests that a greater development of the stock market improves bank profitability. Hence, the positive and statistically significant of the stock market capitalization to the GDP indicates that a larger stock market compared to the economy or the banking sector increases the bank profits. These results are in accordance with those of Demirguc-Kunt and Huizinga, (2001) who found that even in the underdeveloped financial systems, the development of the stock market improves performance.

\section{Macroeconomic Variables}

The macroeconomic indicators, that is to say, inflation and economic growth (Table 5):

The researchers notice that the relationship between inflation (INF) and bank profitability is negative. This implies that during the period of our study, inflation has brought an increase in costs higher than the revenues as a negative relationship between inflation and profit.

The results, regarding the impact of the economic growth (GDPGR) on the bank profitability of the Tunisian deposit banks (SOP), are in accordance with those of Kosmidou et al., (2005) which brought more support to the argument of the negative association between the economic growth and the financial performance of the sector. 
Table 6 - Results of the Search

\begin{tabular}{|l|c|c||}
\hline & Expected sign & Found sign \\
\hline BLOAN & $(+)$ & $(+)$ \\
\hline LIQ & $(-)$ & $(-)$ \\
\hline EQAS & $(+)$ & $(+)$ \\
\hline SIZE & $(?)$ & $(+)$ \\
\hline CONC & $(+)$ & $(+)$ \\
\hline ASSGDP & $(+)$ & $(-)$ \\
\hline MACPASS & $(-)$ & $(-)$ \\
\hline MACGDP & $(+)$ & $(+)$ \\
\hline GDPGGR & $(+)$ & $(-)$ \\
\hline INF & $(?)$ & $(-)$ \\
\hline
\end{tabular}

\section{Conclusion}

In this paper, the researchers analyzed the effect of a set of determinants on the profitability of the Tunisian banks. So, knowing the characteristics of the banks, the macroeconomic conditions and the financial structure have an impact on the bank profitability which is essential not only for the managers of the banks but also for many stakeholders (the central bank, the bankers, the governments and the financial authorities of Tunisia). The conclusions drawn from this study would also be special in the economies and the banking systems undergoing radical changes during this period.

For the reasons mentioned above, this paper has analyzed how the financial characteristics and the banking environment have affected the profitability of banks operating in the Tunisian banking sector. Once gathered, a sample of 12 commercial banks operating during the period 1995-2005 provided a basis for the econometric analysis. The results indicate that the profitability of commercial Tunisian banks, regardless of their property, is affected by the internal characteristics and the environmental changes in the whole banking sector.

As expected, the coefficient of the ratio of equity capitals to assets was positively related to profitability and seems to be the most significant determinant of the profitability of the national banks by giving support to the argument that wellcapitalized banks face lower bankruptcy costs, which reduces their investment cost. The relationship between size and profitability was also positive since it shows the existence of economies of scale in the Tunisian banking sector. The impact of the credit risk variables and the liquidity risk is not significant, and therefore, more researches are required.

By turning to the macroeconomic variables, it is found that the GDP growth and inflation are not significant and have negative signs related to the bank profitability. These results about the macroeconomic conditions could be attributed to different levels of knowledge of the macro-economic conditions of our country and to the expectations concerning inflation. Besides, banks tend to serve customers from different segments, but react differently in the same macroeconomic conditions. Consequently, the results indicate that MACPASS and MACGDP are statistically significant with opposite signs related to bank profitability, which means that there is substitutability between the bank and the stock market. Finally, the ASSGDP is negatively related to profitability, while the concentration impact on profitability is positive and statistically insignificant which does not confirm the hypothesis of a StructureConduct-Performance paradigm.

Although the latter are aware of the banking performance, the researchers believe that they are insufficient. These approaches appear to be incomplete in that they do not take into account the mechanisms of governance which have an 
important role in the functioning and performance of a bank. It is therefore necessary to integrate these aspects in future researches.

\section{References}

Angbazo, L. (1997). “Commercial Bank Net Interest Margin, Default Risk, Interest Rate Risk, and off-Balance Sheet Banking," Journal of Banking and Finance, 21, 55-87.

Athanasoglou, P., Delis, M. \& Staikouras, C. (2006). "Determinants of Bank Profitability in the South Eastern European Region," Working Paper, Bank of Greece $\mathrm{N}^{\circ} 47$ September 2006.

Barth, J. R., Caprio, G. \& Levine, R. (2004). "Bank Regulation and Supervision: What Works Best?," Journal of Financial Intermediation, Vol (13) Pp 205-248.

Berger, A. N. (1995a). "The Profit Structure Relationship in Banking: Tests of Marketpower and Efficient-Structure Hypotheses," Journal of Money, Credit, and Banking, 27, 404-431.

Berger, A. N. (1995b). "The Relationship between Capital and Earnings in Banking," Journal of Money, Credit, and Banking, 27, 432-456.

Berger, A. N., Demirguc-Kunt, A., Levine, R. \& Haubrich, J. G. (2004). "Bank Concentration and Competition: An Evolution in the Making," Journal of Money, Credit and Banking, Vol. 36, No. 3 Pp. 43351.

Berger, A. N., Hanweck, G. A. \& Humphrey, D. B. (1987). "Competitive Viability in Banking: Scale, Scope and Product Mix Economies," Journal of Monetary Economics, $\mathrm{N}^{\circ} 20$, Pp. 501-520.

Bikker, J. A. \& Bos, J. W. B. (2005). Trends in Competition and Profitability in the Banking Industry: A Basic Framework", SUERF - The European Money and Finance Forum, 2005/2.

Bikker, J. A. \& Hu, H. (2002). "Cyclical Patterns in Profits, Provisioning and
Lending of Banks and Procyclicity of the New Basel Capital Requirements," Banca Nazionale Del Lavaro, Quarterly Review, ${ }^{\circ}$ 55, Pp. 143-175.

Bourke, P. (1989). "Concentration and Other Determinants of Bank Profitability in Europe, North America and Australia," Journal of Banking and Finance, 13, 65-79.

Boyd, J. H. \& Runkle, D. E. (1993). "Size and Performance of Banking Firms:Testing the Predictions of Theory," Journal of Monetary and Economics, 31, 47-67.

Boyd, J. H. \& Smith, B. D. (1996). "The CoEvolution of the Real and Financial Sectors in the Growth Process," World Bank Economic Review, 10, 371-96.

Brock, P. L. \& Suarez, L. R. (2000). "Understanding the Behavior of Bank Spreads in Latin America," Journal of Development Economics, 63, 113-134.

Buser, S. A., Chen, A. H. \& Kane, E. J. (1981). "Federal Deposit Insurance, Regulatory Policy, and Optimal Bank Capital," The Journal of Finance, Vol. 36, No. 1, Pp. 51-60.

Claeys, S. \& Vennet, R. V. (2008). "Determinants of Bank Interest Margins in Central and Eastern Europe: A Comparison with the West," Economic Systems, Vol. 32, No. 2, Pp 197-216.

Cooper, M., Jackson, W. \& Patterson, G. (2003). "Evidence of Predictability in the Cross-Section of Bank Stock Returns," Journal of Banking and Finance, Vol. 27, Pp. 817-50.

Corvoisier, S. \& Gropp, R. (2002). "Bank Concentration and Retail Interest Rates," Journal of Banking and Finance, 26, 21552189.

De Bandt, O. \& Davis, E. P. (2000). "Competition, Contestability and Market Structure in European Banking Sectors on the Eve of EMU," Journal of Banking and Finance, 24(6), 1045-1066.

Demirguç-Kunt, A. \& Huizinga, H. (1999). "Determinants of Commercial Bank Interest 
Margins and Profitability: Some International Evidence," World Bank Economic Review, 13, 379-408.

Demirgüç-Knut, A. \& Huizinga, H. \& Jel Classification, G. (2001). Financial Structure and Bank Profitability, Financial Structure and Economic Growth, Boston: MIT Press, Pp.243-261.

Demirgüç-Kunt, A., Laeven, L. \& Levine, R. (2003). The Impact of Bank Regulations, Concentration, and Institutions on Bank Margins, The World Bank Development Research Group.

Demirguç-Kunt, A. \& Maksimovic, V. (1996). "Stock Market Development and Financing Choices of Firms," The World Bank Economic Review, 10 (2): 341-69.

Duca, J. V. \& Mclaughlin, M. M. (1990). "Developments Affecting the Profitability of Commercial Banks," Federal Reserve Bulletin, Issue Jul, Pp. 477-499.

Eichengreen, B. \& Gibson, H. D. (2001). Greek Banking at the Dawn of the New Millennium, CERP Discussion Paper No. 2791.

European Commission (1997). 'Impact on Services: Credit Institutions and Banking', Single Market Review,' Subseries II, Vol 4., London: Office for Official Publications of the European Communities and Kogan Page Earthscan.

Financial Stability Review (2000), "The Financial Stability Conjuncture and Outlook," The UK Financial System, December.

Gilbert, R. A. (1984). "Studies of Bank Market Structure and Competition," A Review and Evaluation, Journal of Money, Credit and Banking, 16, Pp. 617 - 645.

Goddard, J., Molyneux, P. \& Wilson, J. 0. (2004). "The Profitability of European Banks: A Cross-Sectional and Dynamic Panel Analysis," Manschester School Review, Vol. 72, N³, Pp. 363-383.
Golin, J. (2001). The Bank Credit Analysis Handbook: Aguide for Analysis, Bankers and Investors, John Wiley \& Sons (Asia) Pre Ltd.

Gondat-Larralde, C. \& Lepetit, L. (2001). "The Impact of Market Structure and Efficiency on Bank Profitability: An Empirical Analysis of Banking Industries in Central and Eastern Europe," In: Dickinson, D.G., Mullineux, A.W. (Eds.), Financial and Monetary Integration in the New Europe. Convergence between the European Union and Central and Eastern Europe, Edward Elgar, 2001.

Gury, B. K., Staunton, J. \& Balashanmugam, B. (1999). 'Determinants of Commercial Bank Profitability in Malaysia,' Paper Presented at the 12th Annual Australian Finance and Banking Conference, Sydney, Australia, 16-17 December.

Hansan, J. A. \& Rocha, R. R. (1986). 'High Interest Rates, Spreads and the Cost of Intermediation: Two Studies,' Industry and Finance Series 18. World Bank, Industry Department, Washington, D.C.

Hassan, M. K. \& Bashir, A.- H. M. (2003). "Determinants of Islamic Banking Profitability," Paper Presented at the Economic Research Forum (ERF) 10th Annual Conference, Marrakesh-Morocco, 16-18 December.

Hausman, J. A. (1978). "Specification Tests in Econometrics," Econometrica, Vol. 46, No. 6, Pp. 1251-71.

Ho, T. S. Y. \& Saunders, A. (1981). "The Determinants of Bank Interest Margins: Theory and Empirical Evidence," Journal of Financial and Quantitative Analysis, Vol. 16, $\mathrm{N}^{\circ}$ 4, Pp. 581-600.

Kennedy, P. (1985). A Guide to Econometrics, Second Edition, The MIT Press, Cambridge.

Kosmidou, K. (2008). "The Determinants of Banks' Profits in Greece During the Period of EU Financial Integration," Managerial Finance, (Forthcoming). 
Kosmidou, K., Pasiouras, F., Doumpos, M. \& Zopounidis, C. (2004). "Foreign Versus Domestic Banks' Performance in the UK: A Multicriteria Approach," Computational Management Science, 1 (3-4), 329-343.

Kosmidou, K., Tanna, S. \& Pasiouras, F. (2005). "Determinants of Profitability of Domestic UK Commercial Banks : Panel Evidence from the Period 1995-2002," Money Macro and Finance (MMF) Research Group Conference 2005.

Maudos, J. \& de Guevera, J. F. (2004). "Factors Explaining the Interest Margin in the Banking Sectors of the European Union," Journal of Banking and Finance, Vol. 28, 2259-2282.

Miller, S. M. \& Noulas, A. G. (1997). "Portfolio Mix and Large-Bank Profitability in the USA," Journal of Applied Economics, 29(4), P.505-512.

Molyneux, P. \& Thornton, J. (1992). "Determinants of European Bank Profitability: A Note," Journal of Banking and Finance, $\mathrm{N}^{\circ} 16$, Pp. 1173-1178.

Naceur, S. B. (2003). "The Determinants of the Tunisian Banking Industry Profitability: Panel Evidence," In: Paper Presented at the Proceedings of the Economic Research Forum (ERF) 10th Annual Conference, Marrakesh-Marocco, Decembre 16-18, 2003.

Naceur, S. B. \& Goaied, M. (2005). "The Determinants of Commercial Bank Interest Margin and Profitability: Evidence from Tunisia," Under Review at the Journal of Frontiers in Economics and Finance, Pp. 123.

Pallage, S. (1991). "An Econometric Study of the Belgian Banking Sector in Terms of Scale and Scope Economies," Cahiers Economiques De Bruxelles, 130, 126-143.

Pasiouras, F. \& Kosmidou, K. (2006). 'Factors Influencing the Profitability of Domestic and Foreign Commercial Banks in the European Union,' Research in International Business and Finance, Pp. 116.
Pasiouras, F. \& Kosmidou, K. (2007). "Factors Influencing the Profitability of Domestic and Foreign Commercial Banks in the European Union," Research in International Business and Finance, Vol 21, Issue 2, Pp. 222-237.

Pasiouras F., Kosmidou K. \& Gaganis, C. H. (2005). 'A Pooled Study of the Internal and External Determinants of Australian Banks Profits and Margins,' Working Paper, Financial Engineering Laboratory, Department of Production Engineering and Management, Technical University of Crete.

Perry, P. (1992). 'Do Banks Gain or Lose From Inflation,' Journal of Retail Banking, Vol 14, No 2, Pp 25-30.

Revell, J. (1979). 'Inflation and Financial Institutions,' Financial Times, London.

Rodriguez, J. R. O., Alvarez, A. A. \& Gomez, P. P. (1993). Scale and Scope Economies in Banking: A Study of Savings Banks in Spain, (Tenerife: Universidad De Lalaguna).

Saunders, A. \& Schumacher, L. (2000). "The Determinants of Bank Interest Rate Margins: An International Study," Journal of International Money and Finance, Vol. 19, $\mathrm{N}^{\circ}$ 6, Pp. 813-832.

Short, B. K. (1979). "The Relation between Commercial Bank Profit Rates and Banking Concentration in Canada, Western Europe and Japan," Journal of Banking and Finance, 3, Pp. 209 - 219.

Staikouras, C. H. \& Wood, G. (2003). 'The Determinants of Bank Profitability in Europe,' Paper Presented at the European Applied Business Research Conference, Venice, Italy, 9-13 June.

Stiglitz, J. E. \& Uy, M. (1996). "Financial Markets, Public Policy, and the East Asian Miracle," World Bank Research Observer, World Bank Vol. 11, Issue 2 Pp. 249-276.

Valverde, S. C. \& Fernandez, F. R. (2007). "The Determinant of Bank Margins in European Banking," Journal of Banking and Finance, Vol 31, N²7, Pp 2043-2063. 
Vennet, R. V. (1998). "Cost and Profit Dynamics in Financial Conglomerates and Universal Banks in Europe," Presented at the Societe Universitaire Europeenee De Recherchers Financiers/CFS Colloquium, Frankfurt, 15-17 October. 